\title{
PERILOUS PETRODOLLARS: The Effects of Oil Wealth on Democratization
}

THIS PAPER EXAMINES THE RELATIONSHIP BETWEEN OIL WEALTH AND DEMOCRATIC REFORM. THIS RELATIONSHIP IS ESPECIALLY PROBLEMATIC FOR STATES THAT WERE LESS DEVELOPED PRIOR TO THE DISCOVERY OF OIL. THE LARGE OIL REVENUES OF AUTHORITARIAN RENTIER STATES, COUPLED WITH LIMITED MECHANISMS FOR DISTRIBUTIONALACCOUNTABILITY AND POLITICAL PARTICIPATION, ENSUREADIFFICULTROAD AHEAD FOR DEMOCRATIC REFORMS IN SUCH COUNTRIES. AS LONG AS GLOBAL DEPENDENCE ON OIL PERSISTS, THE INTERNAL POLITICS OF OIL-RICH STATES WILLREMAIN EXTREMELY IMPORTANT. HENCE, IT IS NECESSARY TO UNDERSTAND THE WAYS IN WHICH OIL IMPEDES DEMOCRACY IN ORDER TO LOOK FOR VIABLE SOLUTIONS. 


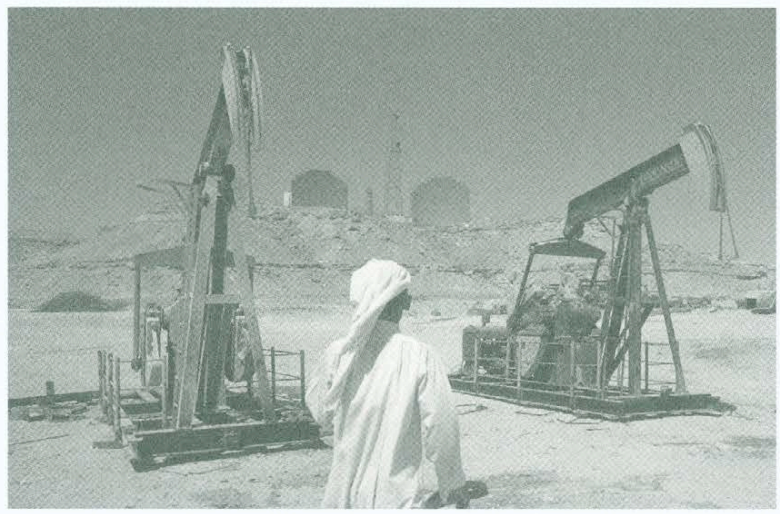

Development theory, such as that put forth by S.M. Lipset, suggests that increased wealth in a state often aids in the process of democratization. This suggestion, however, is questionable in the case of oil-producing states. Despite the fact that these states have benefited immensely from global markets dependent on their "black gold," a telling number of oil-rich states are not democratic. When it comes to the promotion of democracy, one cannot help but ask whether oil wealth is a blessing or a curse. Does wealth generated in less-developed countries allow for greater redistribution and thus enable democracy, as development theories might suggest? Or, does tremendous oil wealth hobble democracy as it funds authoritarian regimes and undermines political participation? An analysis of crossnational data taken over an extended period of time upholds the theory that oil impedes democracy. ${ }^{\mathrm{ii}}$ In this essay I seek to defend the oil-impedes-democracy claim and explicate the channels through which the impediment occurs. I will only be looking at states that were poor preceding the discovery of oil, as the relation to oil differs in countries that were wealthy and diverse prior to oil discovery. Three main explanations have emerged in the oilimpedes-democracy discourse. I will first look at the nature of the oil-rich rentier state and its various effects on the promotion of democratic principles. Next, I will consider the use of repression, made possible by vast oil wealth, as a tool for preventing political change and democratization. I will then address the argument that oil wealth weakens social mobilization and processes of modernization, which are important factors in democratization. There are, of course, challenges to these explanations. Several theorists have proposed ways in which the difficulties generated by oil wealth may be overcome by oil-rich countries, and thus spur progress towards democracy.

Oil-rich states of the Middle East and Northern Africa that derive most of their revenue from foreign-paid oil rent are essentially rentier states. ${ }^{i i i}$ The rentier state is distinguished by several characteristics. A rentier state, first, receives payment of rents from foreign actors; these revenues accrue directly to the state rather than to private individuals

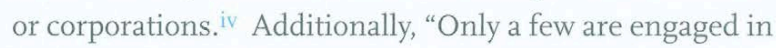
the generation of this rent (wealth), the majority being only involved in the distribution or utilization of it." ${ }^{\vee}$ The nature of the rentier state has great implications for democratization. A vast accumulation of oil wealth relieves the state from having to tax citizens, making distribution rather than extraction its primary function. ${ }^{\mathrm{vi}}$ This "taxation effect," according to Michael Ross, undermines pressures for democracy because "the public in turn will be less likely to demand accountability from - and representation in - their government."vii With citizens unable to demand representation, there exists a detrimental gap between the extent of state power and the weak or nonexistent mechanisms for accountability to the public.

As the gap between state and society grows, the absence of a mechanism for accountability can lead to unrestricted abuse of state power, widespread corruption, and patronage politics. In rentier states, oil revenues can be used to fund assistance programs in order to temper social unrest and pressures for democratization. viii Programs in Saudi Arabia and Libya financed by oil revenues are prime examples of this "spending effect." ix Spending can be employed not just to quiet dissent but also to establish a clientele class. Those seeking a share of oil rents must "form tight links with politicians and bureaucrats in order to offer favors for benefits received." $\times$ The promise of petrodollars gives rise to state-dependent groups with a keen interest in keeping the regime in power while encouraging wide- 
spread corruption. Any desire for democratic reforms "must be made in opposition to powerful countervailing social classes and groups that have become accustomed to the advantages of a petroleum-led development model."xi 'The use of patronage to quell dissent or foster allegiance by allocating income to specific societal sectors is a major obstacle for democratization in oil-rich rentier states.

\section{"The promise of petrodollars gives rise to state-dependent} groups with a keen interest
in keeping the regime in
power, while encouraging
widespread corruption."

Not only does the rentier state establish dependent social groups, but it also undermines the formation of independent groups who may pressure for change. According to Ross, "when oil revenues provide a government with enough money, the government will use its largesse to prevent the formation of social groups that are independent from the state and hence they may be inclined to demand political rights."xii The absence of independent social groups is particularly harmful for democratization, as the existence of civil society is arguably a precondition for democracy. As other scholars argue, the "group formation" effect in rentier states impedes the formation of civic institutions that can serve as channels between the individual and the state; with these channels absent, successful democratic governance is unlikely.xiii Academic studies of countries such as Algeria, Iran, and Iraq support this theory. xiv
The nature and implications of the rentier state are not the only arguments made in the oil-impedes-democracy discourse. The tendency for repression in oil-rich states is also worth noting. The enormous revenues generated by oil wealth have been linked to repressive authoritarian states in many places around the world. "Resource wealth," according to Ross, "may allow their governments to spend more on internal security and so block the population's democratic aspirations." $x v$ In some cases this is done in the interest of perpetuating authoritarian rule in the face of popular pressure. By accumulating greater military might, the state gains a greater ability to suppress dissent. Much of the revenues generated by oil have funded weapons purchases, as in the case of Iran and Iraq during the r970s and I980s. xvi It was oil wealth that made Saddam Hussein "a greater power in his region than he would have been otherwise by allowing him to buy more weapons and build a larger army than he could have produced on his own."xvii Additionally, oil revenues can be used to build large intelligence-gathering apparatuses, as seen in the case of Saudi Arabia, which can serve to coerce and constrain freedoms of expression, organization, and mobilization.xviii Many states with significant oil resources have been plagued by ethnic or regional conflict. These states may use oil wealth to repress such movements under strong authoritarian rule. Chances for democracy are stifled under a repressive authoritarian regime as "these disputes may lead to larger military forces and less democracy in resource-rich, ethnically fractured states."xix Angola, Nigeria, and the Democratic Republic of Congo are examples of the repression effect.xx The military might purchased with oil wealth hobbles democratization by giving the state a means to silence calls for political reform and participation.

The final argument for the oil-impedes-democratization position stems from modernization theory. This theory "holds that democracy is caused by a collection of social and cultural changes-including occupational specialization, urbanization, and higher levels of education-that are in turn caused by economic development."xxi As oil can im- 
pede economic development, prospects for democratization suffer. One of the ways in which oil inhibits economic development is known as the Dutch disease. As was the case in the Netherlands, a reliance on oil resources "actually inhibits the development of agriculture or industry by encouraging overvalued exchange rates, which, in turn, promote a reliance on imports, services, and speculative activity rather than long term investment."xxii While the oilrich rentier state may grow extremely wealthy, it does so without investment in and modernization of its domestic economy. In fact, the generation of oil rents has "almost nothing to do with the productive processes of the domestic economy."xxiii Additionally, oil production is capital intensive and not labor intensive. This hinders the creation of an internal labor market. The lack of a strong and diversified domestic and labor market inhibits industrialization, specialization, and urbanization-all important factors in modernization. Furthermore, the need for highly technical skill sets can lead to the use of foreign labor. Since foreign laborers are not citizens, they are not likely to have a vested interest in the country or a desire to pressure the regime for democratic reform. As Eric Davis notes, "In Saudi Arabia and the Arab Gulf states, the expatriate labor force ... often outnumbers the indigenous population." xxiv Foreign labor may have an interest in maintaining the existing political and economic system so as to remain employed. Additionally, because these better-paid oil workers are not employed in large numbers, a labor aristocracy arises, once again at the expense of democracy.xxv Oil-led economic development may also inhibit processes of social mobilization as "the failure of the population to move into industrial and service sector jobs renders them less likely to push for democracy."xxvi The absence of large numbers in the tertiary sector results in a less autonomous workforce, "[un]accustomed to thinking for themselves on the job and having specialized skills that enhance their bargaining power against elites."xxvii Without an autonomous workforce, the public is ill-equipped to organize and communicate calls for reform. Oil wealth also tends "to impede the development of institutions and values critical to open, marketbased economies and political freedom: civil liberties, the rule of law, protection of property rights, and political participation."xxviii Without these institutions and values, prospects for social mobilization suffer. Weakened social mobilization, coupled with inadequate development and modernization, decreases the likelihood of democratization.

Though a general consensus exists about the negative correlation between democracy and oil, it need not mean that oil-rich states are doomed to remain undemocratic. Several scholars argue that with the proper approach, the curse of oil wealth can be overcome. Indeed, they cite several reform-oriented oil-rich states as examples. Gwenn Okruhlik argues that oil, rather than stifling calls for reform, can actually produce opposition movements. She suggests, "Wealth generated through oil receipts is a catalyst for opposition to the state, rather than a tool to placate dissent."xxix Essentially, she argues that states engender their own opposition by prompting resentment over unequal distribution and providing dissenters with resources necessary for mobilization. $x x x$ She cites the November I990 business petition and women's protest in Saudi Arabia as examples of civil pressures for reform.xxxi Additionally, reforms in several other Arab Gulf monarchies support the claim that oil-rich states are not necessarily free from popular pressure for reform. "In view of the grave economic difficulties and social tensions," Anushirivan Ehteshami argues, the Gulf monarchies "have had little choice but to consider the introduction of

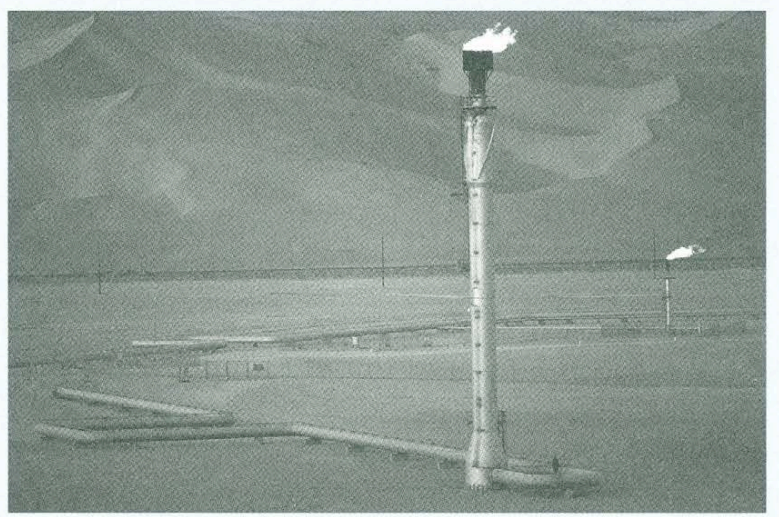


economic and political reforms."xxxii Indeed, states such as Kuwait, Qatar, Oman, and Bahrain have taken important steps towards liberal reforms, such as expanding elected assemblies, allowing for political debate, and even widening political rights of women.xxxiii In Bahrain, the establishment of a consultative council, the National Charter, and a constitutional monarchy during the mid-I99os shows that oil wealth need not inhibit democratic reform in oil-rich states.xxxiv While these countries are still a long way from meeting internationally recognized criteria of good governance, important steps have been made towards the likelihood of democratization.

Alternatives for managing oil wealth have also been proposed as a way to overcome the predictions of the oilimpedes-democracy discourse. One alternative proposed by Birdsall et al. is the creation of "special oil funds which constitutional or other restrictions on the use of revenues-[which have] been used in Kuwait and Norway for several decades, and in Colombia and Venezuela since the I990s."Xxxy The national oil funds, though often difficult to implement, aim to insulate oil wealth from corruption and to ensure governments focus spending on socially beneficial projects. Another alternative for managing oil wealth is by distributing it directly to the people rather than funneling it into the state treasury. This would minimize the opportunity for corruption and patronage politics, while sub. stantially increasing income per capita in underdeveloped countries. xxxvi A distribution-based policy could aid in economic diversification and investment in infrastructure, while promoting the development of domestic markets and local politics. ${ }^{x x x v i i}$ Though this policy might be more difficult to implement, encouraging greater scrutiny of spending projects would prove beneficial for democratization. A third alternative for managing oil wealth calls for international supervision of implementation, ideally under the direction of the UN. While this would require a temporary forfeiture of some sovereignty, international pressure could ensure greater demands for accountability and trans. parency. This option is particularly pertinent for Iraq, given its current situation. Supervision by an international body "may be the only practical way to develop democratic institutions free of the corrupting influence of oil and to ensure the long-term economic and political empowerment of ordinary Iraqis."xxxviii Though alternatives have surfaced, the oil-impedes-democracy debate is far from resolved. The effects of successful implementation of these ameliorative policies still remain to be seen and democracy in many oil-rich states is a long way off.

\section{"Despite the fact that}

\section{these states have benefited} immensely from global markets dependent on their "black gold," a telling number of oil-rich
states are not democratic."

Despite the fact that there has been some visible progress in several states in the oil-rich Middle East, widespread prodemocratic change is far from the norm. Oil wealth is still an impediment for democracy in much of the world. The enormous oil revenues of authoritarian rentier states coupled with limited mechanisms for distributional accountability and political participation ensure a difficult road ahead for democratization. As long as global dependence on oil persists, the politics of these regions remain important. Hence, it is necessary to understand the ways in which oil impedes democracy in order to look for viable solutions. Authoritarianism in oil-rich states is not inevitable. If democracy is to flourish in such regions, however, states must learn to cope with the complex challenges of this natural resource. 


\section{ENDNOTES}

i. Birdsall and Subramanian $(77-89)$

ii. See results of Michael L. Ross' regression analysis in, Ros: (325-6I)

iii. Okruhlik (295)

iv. Ross (329)

v. Beblawi and Luciani (5I)

vi. Okruhlik (296)

vii. Ross (332)

viii. Maugeri (I65-174)

ix. Ross (333)

x. Karl (57)

xi. $\operatorname{Karl}(54)$

xii. Ross (334)

xiii. Ross (334)

xiv. Ross (334)

$\mathrm{xv}$. Ross (335)

xvi. Tétreault (268)

xvii. Tétreault (269)

xviii. Okruhlik (3OI)

xix. Ross (336)

$x x$. Ross (336)

xxi. Ross $(336$

xxii. Karl (53)

xxiii. Karl (48)

xxiv. Davis (18)

xxv. Karl (52-53)

xxvi. Ross (357)

xxvii. Ross (336)

xxviii. Birdsall (77)

xxix. Okruhlik (297)

xxx. Okruhlik (297)

xxxi. Okruhlik (302)

xxxii. Ehteshami (54)

xxxiii. Ehteshami $(62-67)$

xxxiv. Ehteshami (65-66)

xxxv. Birdsall and Subramanian (80-89)

xxxvi. Birdsall and Subramanian (80-80)

xxxvii. Birdsall and Subramanian (80-89)

xxxviii. Birdsall and Subramanian (88-89)

\section{REFERENCES}

Beblawi, Hazem, and Giacomo Luciani. 1987. The Rentier State. London: Croom Helm.

Birdsall, Nancy and Arvind Subramanian. 2004. "Saving Iraq From Its Oil." Foreign Affairs, 83(4): pp. 77-89, July/August.

Davis, Eric. 199I. "Theorizing Statecraft and Social Change in Arab Oil-Producing Countries." in Davis and Gavrielides (eds.), Statecraft in the Middle East: Oil, Historical Memory and Popular Culture. Miami: Florida International University Press: pp. 1-35.
Ehteshami, Anushirivan. 2003. "Reform from above: the Politics of Participation in the Oil Monarchies." International Affairs 79(I): pp. 53-75, January.

Karl, Terry Lynn. 1997. The Paradox of Plenty: Oil Booms and Petro-States. Berkeley: University of California Press.

Maugeri, Leonardo. 2003. "Not in Oil's Name." Foreign Affairs 82:4: pp. 165 , July-August.

Okruhlik, Gwenn. 1999. "Rentier Wealth, Unruly Law, and the Rise of Opposition: The Political Economy of Oil States." Comparative Politics 3I(3): pp. 295-315, April.

Ross, Michael L. 200I. “Does Oil Hinder Democracy?” World Politics 53(3): 325-61, April

Tétreault, Mary Ann. 2004. "The Political Economy of Middle Eastern Oil." in Deborah J. Gerner and Jillian Schwedler (eds.) Understanding the Contemporary Middle East. London: Lynne Rienner Publishers: pp. 249-272. 